\title{
Henrik Ibsen's The Master Builder as a Case Study of Pre-Freudian Psychiatry
}

\section{Hansgerd Delbrück}

Written in 1892 when Ibsen, aged 64, was already a world-famous, if highly controversial, playwright, The Master Builder was first produced in January 1893 in Trondheim and Berlin, and soon afterwards had its premieres in a number of other European capitals: in London (February of the same year), Copenhagen (March), and Paris (April). 1900 saw its first production in America (New York) and 1905 in Russia (St. Petersburg). ${ }^{1}$ These dates mark the beginnings of an impressive stage history; even the London critics, who at the time of the premiere were almost unanimous in writing scathing reviews of the play, admitted that in spite of their own severe misgivings about its message, which they found incomprehensible and "the most dreary and purposeless drivel," the production was well received by the general public, since the actors "never let the attention of [the] audience run loose." 2 And interest in the play was never restricted to the stage. While its New Zealand professional theatrical premiere took place as recently as March $1995^{3}$, it had already been a set text in New Zealand university courses for decades.

Both The Master Builder's popularity and the controversy it has generated can largely be attributed to the many issues it raises: the generation gap, sexual obsession, the capitalist exploitation of labour ${ }^{4}$ and of women, and the relationship between science and

\footnotetext{
${ }^{1}$ See the table of the play's stage history from January 1893 to October 1983 in George B. Bryan, An Ibsen Companion: A Dictionary-Guide to the Life, Works, and Critical Reception of Henrik Ibsen (Westport: Greenwood Press, 1984), 24950 .

2 Thirteen reviews, which appeared in London from 17 February until 4 March 1893, are collected in Ibsen, The Critical Heritage, ed. Michael Egan (London, Boston: Routledge and Kegan Paul, 1985), 275 and 270 respectively.

${ }^{3}$ In the Circa Theatre, Wellington, directed by Colin McColl.

${ }^{4}$ After the premiere of Baumeister Solness in Berlin, the German critics were for the most part as confused by the symbolism of the play as their London counterparts. However, Franz Mehring, a German historian and politician from the far left of the Social Democrats, praised Ibsen for attacking, in his protagonist
} 
religion, myth and folklore. As to its form, critics have both praised and condemned the way in which the play combines and unifies or, alternatively, mixes unsatisfactorily, such diverse literary styles as realism, symbolism and mythology. There has also been interest in the connections between its protagonist and the playwright, not only because of Ibsen's own struggle with his ideal of the playwright as artist, but also because of a romantic attachment he had with an eighteen year old Viennese girl ${ }^{5}$ during a holiday in the Tyrol in August 1889, not long before he wrote his play about Solness' fatal attachment to Hilde. While to varying degrees I feel indebted to all these approaches, in this essay I intend to focus on an aspect of the play that seems to owe something to Ibsen's interest in medicine. This appears to have been an ongoing preoccupation of his, even though his plans to study medicine at university never materialised because he failed the entrance exams in Mathematics and Greek. Thus, while many nineteenth-century playwrights were concerned with psychology, in The Master Builder Ibsen shows a distinct interest in psychiatry, that is to say in the medical aspects of psychology. In this context it should be noted that Ibsen published his play one year before Sigmund Freud and Josef Breuer published the first results of a treatment based on what they called the cathartic method, and also that the publication of Freud's Essays on Hysteria (another collaborative effort with Breuer) was still three years away, and the publication of his theory of the Oedipus complex a full 18 years. One is thus well advised to embark on an investigation of the role of psychiatry in The Master Builder without any Freudian preconceptions.

Late nineteenth-century society was not yet ready for an objective and open discussion of psychiatric illnesses, which were seen as so many forms of "madness," a taboo subject. "Thus in The

Solness, the strong-men of capitalism as brutal and cowardly oafs ("brutale und feige Lümmel"). See Ibsen auf der deutschen Bühne: Texte zur Rezeption, ed. Wilhelm Friese (Tübingen: Niemeyer, 1976), XVII (introduction by the editor) and 95 .

${ }^{5}$ For a detailed documentation of Ibsen's relationship with Emilie Bardach, see Michael Meyer's introduction to Henrik Ibsen, The Master Builder, trans. Michael Meyer (London: Hart-Davis, 1961), 7-29.

${ }^{6}$ In Norway, an Act of 1848 made the development of the mental health system a national goal, and psychiatric hospitals were slowly established from 1855 . However, "conditions within the mental health sector were far from satisfactory 
Master Builder, too, Ibsen's concern with psychiatry, as distinct from the simple mention of "madness," can only become apparent to an audience that is prepared to appreciate the play's hidden messages. On an overt level, Solness' crisis has three main causes: his professional insecurity, his marriage problems, and his mid-life crisis. By the end of the play, however, when his fate as a master builder, as a husband and as a lover have become one and the same thing, it becomes clear that these three factors in combination point to what is in effect a psychiatric condition. The nature of this condition is further complicated by the fact that the three women in Solness' life, each in her own way, also behave like pathological cases, thereby obscuring as well as revealing his own psychiatric condition as the primary force behind his death. If we wish to analyse the importance of psychiatry in the play and determine its impact on the play as tragedy, we will therefore need to look at all these factors and, as we do so, to heed James Joyce's warning in his essay, published in 1900, on Ibsen's play When We Dead Awaken: "To begin an account of a play of Ibsen's is surely no easy matter. The subject is, in one way, so confined, and, in another way, so vast."

The importance of the protagonist's occupation to the tragic development is already suggested by the play's Norwegian title, Bygmester Solness. His surname, Solness, is not accompanied by his Christian name, but by the work he does and, more importantly, by his occupational rank. The impression given is of a title backed up by the authority of an official certificate: Solness has reached the highest level of standing available to him in his trade, and should therefore be able to command the highest respect from his fellow citizens, including the use of that title when they address him. However, it soon turns out that he has himself fallen behind the expectations that arise from his title. At the very beginning of act 1 we learn that he has not even mastered the basics of his craft, the mathematical calculations and draftsmanship involved in

until World War II. There was a good deal of unrest in psychiatric hospitals, which were closed institutions and which the public associated with something sinister, prisonlike, and shameful to have dealings with" (Nils Retterstol, "Scandinavia and Finland," in John G. Howells, World History of Psychiatry [London: Bailliere Tindall, 1975], 217-18).

7 James Joyce, "Ibsen's New Drama," in The Critical Writings of James Joyce, ed. Ellsworth Mason and Richard Ellmann (London: Faber and Faber, 1959), 49. 
designing buildings, and that his own employees despise him for it. When Ragnar Brovik, the apprentice, calls him the master builder, he does so with bitter sarcasm. ${ }^{8}$ Solness, aware that the calculations need to be done accurately for his designs to result in structurally sound buildings, has employed Ragnar and his father Knut to do the drafting for him. Knut Brovik is old and sick and cannot be expected to be of help for much longer, but Ragnar, although only self-taught, is proving to be particularly good at doing the calculations, and has voiced his aspirations to start his own business. Solness feels threatened by this and is prepared to compromise his moral standards to prevent him from doing so: against his own knowledge of the facts, he insists that the apprentice has not yet learnt enough to design his own plans. This may appear at first like a desperate act; however, it soon becomes clear that it is not the first time that Solness has shown himself willing to compromise the rules of common human decency for the sake of his business. In fact, his lack of moral standards goes back to the very beginning of his career when, at that time himself the apprentice of old Brovik, he overtook his master by crooked means, so that the latter ended up as his employee. And the same ruthlessness can be observed when he first appears on stage, in his treatment of Ragnar's fiancée, Kaja Fosli, the first of the three women in his life to appear in the play. He has employed her as his secretary and drawn her into a bizarre love affair with him, which, as far as he is concerned, is never meant to be consummated: he only wants her infatuation as a means of keeping Ragnar in his grip, who cannot be expected to leave while his fiancée wants to stay with Solness. Yet his relationship with Kaja has evidently put him under some strain. When she "fearfully" and even "desperately" suggests to him that she is willing to break off her engagement with Ragnar if need be, Solness "flar[es] up" and rudely "burst[s] out": "Have you gone mad!". She "looks at him with terror in her eyes," but by then he has succeeded in "controlling himself" and calms her down by talking "gently and

${ }^{8}$ The only other character in the play to address him with his title is his lover Hilde. Although she does so in a positive sense, her use of it is double-edged in that she insists that he should live up to the expectations that go with it. 
quietly to her." Their contrasting response to the strain of their relationship reflects the fact that "[b]y the end of the nineteenth century, two conditions were universally considered to be the main neuroses: hysteria and neurasthenia, the former being mainly a neurosis of women, the latter predominantly a neurosis of men." 10

Solness' relationship with his estranged wife, Aline, is even more complicated. As the woman with whom he has been connected for the longest time, she knows him much more intimately than his secretary, and he is afraid that she might have passed on sensitive information about him to the family doctor, whose professional knowledge about him he perceives as a threat. In a conversation with the physician, who has come to pay a visit to Aline, he voices his suspicion that she and the doctor are doubting his sanity; but when this is emphatically denied by Dr. Herdal, Solness unexpectedly concedes that he may be mad after all, that he lives in the uncontrollable fear of having to give way to younger competitors who are about to come knocking on his door at any moment.

This admission of his own madness sounds rhetorical, as if Solness hopes to be contradicted in order to receive assurance of his sanity. After all, is it not a characteristic of mad people that they are the only ones who believe that they are not? Yet at that moment Hilde Wangel, who will turn out to be the femme fatale in Solness' life, arrives at the door, and it soon becomes apparent, not only that there is indeed something wrong with his mind, or at least his memory, but that his midlife crisis must have been going on for over ten years. He does not recognise Hilde, despite her claim that they met a decade earlier in rather memorable circumstances. She, then a twelve or thirteen-year old girl, had waved at him with a little flag from a crowd of people watching him hang a wreath on the weather cock of the tower he had extended on the old church up north in Lysanger. One can easily understand that Solness does not recognise the grown woman on his doorstep as the young daughter of Dr Wangel in Lysanger; but it seems rather odd that while he can recall having been invited to Dr Wangel's for the

${ }^{9}$ Henrik Ibsen, Four Major Plays, trans. James McFarlane (Oxford, New York: Oxford University Press, 1981), 276-77. (Hereafter page numbers of the play from this translation will be given in brackets immediately after the quotations.)

${ }^{10}$ Henri F. Ellenberger, The Discovery of the Unconscious: The History and Evolution of Dynamic Psychiatry (London: Allen Lane the Penguin, 1970), 244. 
evening after the big dinner in his honour at the club, he should have no memory at all of meeting her alone in the hall of her father's house, where, according to Hilde, he called her a princess, kissed her passionately, and promised to carry her off ten years later into her own kingdom of Orangia. Only with some reluctance does he eventually admit that there may be some truth to her story. Overall, however, he turns out to be surprisingly glad that she has come: he feels lonely and needs her company, and he also needs support in his battle against the young people who are planning to make him the victim of change. Indeed, she is the one person he needs the most. She for her part is so overjoyed to hear this that she feels she has her kingdom already_-"almost" (300).

The healthy, lively young woman seems to Solness in every respect the opposite of his wife Aline to whom he feels chained: "chained to a dead woman" as he puts it in act 3 (338); and Hilde believes that he will be able to give her all the happiness she can imagine, provided that he allows her to solve his problems. We soon discover that these go beyond his present professional insecurity and marital difficulties, to a series of events which reach back even beyond the incident in Lysanger. Kaja enters to announce that old Brovik has fallen very ill and will soon die, and her words remind Aline of the death of her and Solness' barely three-week-old twin boys twelve or thirteen years earlier, in the aftermath of a fire which destroyed the house of her parents, in which she, Solness and the twins had been living. She now reveals to her husband the overwhelming feelings of guilt she has harboured all these years, based on her belief that the twins would still be alive if only she had been "more resolute in misfortune" (335). Yet when Solness confesses that he is weighed down by feelings of guilt towards Aline, she thinks this so strange that she suggests he must be mad after all.

And indeed, it appears that Aline may not be far off the mark when it is revealed that in each of the houses that he has subsequently built for himself and his wife, Solness has included a nursery. Hilde herself considers this somewhat mad and her questions prompt him to tell her about the loss of the twins and to expand on his own feelings of guilt. While the twins did not die in the fire itself, in his view their deaths were indirectly caused by it, and Aline was thus prevented from expressing her natural inner warmth in "building their souls" (317). He reveals to Hilde that he had in fact willed a fire to destroy the house so that he could 
subdivide the property for his building projects. In his opinion it makes no difference that the fire started in a cupboard, whereas he had wanted it to be caused specifically by a crack in the chimney: the fact remains that he willed it to happen in the first place. Hence his great pangs of guilt, although he concedes that he may be completely innocent. It is the uncertainty of his guilt that he feels is driving him to the point of insanity.

Solness' story leads Hilde to diagnose an illness in him, which she assures him has nothing to do with his sanity, but is simply the result of a "fragile conscience" (322) which prevents him from doing what he truly wants. Persuading him that his true desire is to be recognised as a master builder, and that he will never be a great master builder if he continues to depend on anyone but himself, she gets him to write the reference which he had denied Ragnar because he did not want to lose him, and eventually, with her encouragement, Solness becomes so confident that, to Aline's horror, he decides to hang a wreath on the weather cock on top of the tower of his new building. In Aline's eyes this confirms his madness, and she goes off to fetch the doctor to bring him back to his senses, while Hilde insists that the hanging of the wreath is part of the kingdom he had promised her. Aline and the doctor do their best to talk sense into Solness, and Ragnar cannot believe that Solness will make it up to the tower in the first place, but Hilde continues to encourage him all the way. Ironically, however, it is she who brings him down once he has reached the top: disregarding the doctor's warning a minute earlier ("Shh. Don't shout to him!"), she "[s]natches [Aline's] white shawl from the doctor, waves it about and shouts up in the air: Hurrah for the master builder!" (353-54). At that very moment, he plunges down to his death, carrying part of the scaffolding with him. There is a cry of terror from the crowd, Aline faints and even Ragnar is in danger of losing his balance ${ }^{11}$ in the knowledge that "[Solness] must have been dashed to pieces. Killed instantaneously" (354). When the grisly details of Solness' death are confirmed, he is shocked: "This is terrible. So in fact he couldn't do it" (355). Ragnar's comment is an ironic echo of Hilde's repeated reference to Solness' climb to the top of the church tower in Lysanger and of

\footnotetext{
11 The stage directions state that Ragnar is "supporting himself trembling against the railing" (354).
} 
the tower of his new house as 'terribly exciting' (292 and 331); but now, when Solness has actually fallen to his death, she considers it neither exciting nor terrible, but simply refuses to accept the fact: Oblivious to the dead body, she "continues to stare upwards, as though turned to stone." and to insist that he has made it to the top, crying "with a wild intensity": "My ... my ... master builder!" (355).

Thus, in the eyes of Hilde, and of her alone, the play ends in triumph and victory, and her reaction leaves us with a shudder in the face of her madness. However, we are also left wondering about the nature of Solness' madness, and to what extent he himself was responsible for his death. When Aline calls his ambition to climb the tower insane, she is simply thinking of the risk he is taking with his life because of his problem with vertigo. Her view is clearly too narrow: it does not take into account that her husband's madness has become inseparable from that of Hilde from the moment that he allowed her to talk him into climbing the tower. Solness' madness is not identical with Hilde's, but it complements it. If we are to understand how it relates to Hilde, we must therefore investigate her mind first.

Hilde is prepared to identify with Solness on his way to the top and while he is on top, but she can and will not follow him into death as Kleist's Penthesilea had followed Achilles or Shakespeare's Romeo had followed Juliet. Hilde, like Romeo, contributes to her lover's death involuntarily, but, unlike Penthesilea and Romeo, she cannot even feel horror at her lover's death. This paradox, which Ibsen has underlined with the horror voiced by Aline and Ragnar and the crowd, can only be explained from the way in which she internalised her earlier experience of Solness' climbing the tower at Lysanger.

An important part of this is her expectation that his new climb will grant her even greater excitement than she experienced at Lysanger. In act 1, she describes the experience in Lysanger to Solness as "wonderfully exciting, standing down there and looking up at you. Imagine now - if he were to fall! The master builder himself!" (291). The fact that he had not fallen down had curtailed the excitement. However, after Solness had come safely down "the real thing" happened: she was kissed by the man who had built a tower higher than anybody else could. Her sensuous description of the kiss has made some interpreters go so far as to declare that it must have led her to experience orgasm. In any case, it not only 
serves to emphasise that the kiss seemed much more "real" to her than merely watching him standing on the tower, but also gives a sexual dimension to the latter experience, turning it into a kind of foreplay. Of course, the kiss itself proved to be a disappointment, as Solness left Hilde with the excuse that in ten years he would come back and take her off to her kingdom. Now, having come to demand that he honour his promise, she expects at last to experience the ultimate fulfilment which, in Lysanger, neither watching him at the top of the tower nor the kiss had granted her.

Significantly, Hilde never asks Solness directly for a kiss, let alone for a consummation of the relationship that had been interrupted at Lysanger. Rather, Solness' climbing the church tower seems to have retrospectively become such a powerful experience in itself that it is now her main object of fascination: all she talks about is that he should climb the new tower of the house which he has just finished building. What will make this even more thrilling than her earlier experience is the fact that Solness' climb will this time come even closer than in Lysanger to realising her fantasy: "Imagine if he were to fall." However, it is clear, not only from the end of the play, but from her behaviour since her arrival at Solness' door, that she does not really want him to fall to his death. ${ }^{12}$ Certainly, the thrill for which she is yearning will increase as the balance tips toward his death; but his actual death must destroy it.

This is why we see, in her refusal to accept Solness' death at the end of the play, hysteria of much greater severity than had been displayed by Kaja Fossli in act 1. Kaja's hysterical energy subsides by the end of act 2: she shows no more signs of outright terror

12 According to Robyn Young, Time's Disinherited Children: Childhood, Regression and Sacrifice in the Plays of Henrik Ibsen (Norwich: Norvik Press, 1989), 161, "there can be little doubt that the nature of [Hilde's] excitement [by Solness' climb of the tower] derives from adolescent Hilde's equation of sexual fulfilment with death [...]" After stating that "the ambivalence between ecstatic admiration and the fascination with destruction and death is as intrinsic a part of Hilde now as it has been then" (162), she concludes her chapter on The Master Builder by saying that "Hilde herself, at the end of the play, has only managed to create the illusion of 'her' master builder. This, too, is 'the impossible' - a moment which cannot last except in an imagination which can summon up harps in the air" (163). There is no attempt made by Young to discuss why Hilde cannot cope with Solness' death when it actually occurs. 
when she "tremulously" obeys the master builder's command that she retreat into the background. (She is not present when Solness falls to his death.) Kaja is thus changed by the play's events into a helpless, passive being who seems well on her way to becoming a "dead woman" like Aline. This is not a path open to Hilde, as is made clear by the fact that she cannot sustain her position "as though turned to stone" (354), but begins once again to wave her scarf at the tower, where she thinks Solness is still standing. And her final hysteria is also in direct contrast to the development of Aline herself, who goes a long way toward overcoming her condition as a "living dead" in her attempts to prevent Solness from climbing the tower. When Aline faints at the sight of his fall, it is as if she were finally being delivered of a child whose death at the moment of its birth means much more to her than the death of the twins so many years ago. In trying to save her husband, she has been able for the first time in her life to have the equivalent of maternal feelings not only for her dolls, but for a human being of flesh and blood; thanks to Hilde's influence on Solness, Aline, whose emotional capacities had lagged behind her biological development and remained those of a child, has finally developed the emotional attributes of a mother.

It is therefore tragically ironic that the white shawl, the symbol of her new role as a mother to her husband and of the loosening of her fixation on the past, should be used by Hilde ${ }^{13}$ to cause Solness to fall from the tower. Like Aline, Hilde was prevented from maturing into a woman whose emotional age matched her years. However, what in her case developed too fast was not motherhood, but her sexuality, triggered prematurely by Solness in Lysanger. In contrast to Aline, she is fixated not on the past, but on the future. Aline's main concern had continued to be for her dolls even after she became the mother of twins; Hilde's immaturity shows in her unrealistic expectation that her relationship with Solness will grant her the ultimate in sexual fulfilment. She clearly feels the need to postpone a repeat of the kiss until she can be sure that the

\footnotetext{
13 This point is sadly lost in Bernard Shaw's account of The Master Builder in his essay "The Quintessence of Ibsenism," in The Works of Bernard Shaw, vol. 19 (London: Constable, 1930), 103: “[...] and very soon [Hilde] sends him up a tower again (the tower of the new house) and waves her scarf to him as madly as ever. This time he really does break his neck, and so the story ends" (my italics).
} 
excitement of her relationship will not only never end, but perpetually increase.

This goes some way towards explaining why Hilde wants Solness to repeat the climb of the tower. But only by looking more closely at how he falls under her spell will it finally be possible to explain his own fatal psychiatric condition.

In contrast to the past-fixated Aline, who insists that because of the tragic events in the past there can be no future for her and Solness, Hilde is able to transmit to Solness her own view of the past as a key to the wonderful future that he will share with her. She patiently listens to his occupational problems, and with her suggestion that he build "castles in the air" (341) for her, rather than ordinary houses, she re-awakens his original great ambition to be an architect, which he had not been able to fulfil because he could not pass the exams. Furthermore, the castle in the air will be completely reserved for him and Hilde: visible only to them, a product of their imagination alone. Whoever else might witness the act will not understand its meaning. Yet the castle will not be a mere fantasy either: its creation will consist in his climbing the tower and her watching him, a joint act performed in the real world.

Seen objectively, of course, all this requires him to regress to her immature level. He shows a childlike willingness to pull off a dangerous stunt for her, which grows in his imagination into a work of art, rather than simply an acrobatic act. We have already seen Solness' acting abilities displayed in act 1, when he was able to give a sufficiently convincing impression of his love for Kaja to succeed in manipulating her. This time, however, he plays his role, that of the great architect, not in order to manipulate his audience, Hilde, but for her as well as his own enjoyment; and he has no intention whatever of throwing her into the hysterical frenzy that she eventually suffers as the result of his act. Nor is Hilde consciously aware of the danger to his life posed by a performance that both of them regard as great and admirable. Yet, just as her insistence that he perform this stunt is motivated by a subconscious urge to see him fall endlessly but ever closer to his death, his compliance with her wishes seems to originate from an unconscious suicidal urge on his part. Solness' foolhardy compliance with all her suggestions, allowing Ragnar to set up his own business and climbing the tower, only makes sense if death is what he really wants. By giving permission to Ragnar to leave the 
business, he has effectively already signed his own death warrant as a businessman, ${ }^{14}$ and his decision to become a performance artist on Hilde's terms, with her as the sole audience, would be inexplicable madness if he were not now prepared in principle to end his life altogether.

The latent existence of a death-wish in Solness from as early on as his stay in Lysanger can be shown by examining the source of the many instances of his persecution complex. After having successively complained of being persecuted by his wife, Dr Herdal, Ragnar, and young people in general, in act 3 he confides in Hilde that, from the time of the fire, he has in fact felt persecuted by God himself, the most formidable and threatening adversary imaginable. It was God who "let the old house burn down" (348) in order to force Solness to build only churches for Him. Solness "suddenly [...] realized" this while he was finishing the church tower at Lysanger, and his realisation left him so disenchanted with both himself and God that he decided that life, unless he could live it on his own terms, was no longer worth living. Hence his sudden impulse to climb to the top of the tower, a risk that he had never undertaken before because of his fear of heights, where he told God that in the future he would no longer build any churches at all, but only homes for human beings. And because of this, he claims, his fear of heights rests in his fear of God's retribution, not just the simple fear that he might dash himself "to pieces," as Hilde suggests (347). In his view, the fact that he did manage to climb the tower at Lysanger only serves to support him in this belief: he is afraid of a divine retribution which, rather than striking him as death, will manifest itself in the failure of the life he undertook to live on his own terms. In this sense, although he is afraid that it will hit him even harder in the future, God's retribution has already reached Solness before the play begins:

\footnotetext{
${ }^{14}$ Ragnar's desire to set up his own business must make Solness painfully aware of how he himself had tricked old Brovik out of his business as a self-employed architect. As old Brovik is now dying, Ragnar's career move leaves Solness with nothing but the dreaded prospect of a fate similar to old Brovik's: a slow and painful decline towards death, starting with the loss of his business.

${ }^{15}$ Susanne Kramarz, Eyolf: Kinder und Kinderschicksale im Werk Henrik Ibsens (Frankfurt am Main: Lang, 1990), 212, lists the death of Solness, along with the deaths of Eyolf, Borkman, Irene and Rubek, among those deaths in Ibsen's plays that have "suicidal implications."
} 
SOLNESS. But He got His own back later on.

HILDE. What do you mean by that?

SOLNESS [looks at her despondently]. Building homes for the people isn't worth a brass farthing, Hilde. (349)

However, this is by no means all the punishment that he has already had to suffer: in addition, he lives in fear for his own sanity, resulting from his confusion between the conflicting beliefs that, on the one hand, God was behind the fire and, on the other hand, he himself successfully willed it to happen. His confusion shows in his conviction that he is under the influence of a troll (323), of "helpers and servers" (321), and of "[g]ood devils and bad devils," of "[b]lond devils and dark devils" (323): Solness is unsure whether they are exercising their powers in opposition to, or in concordance with the will of God, and whether they are acting for or against his own interests. There is a strange mix of pagan folklore and Christian beliefs at work in his mind, which he is unable to disentangle or account for rationally, as he is not even consciously aware of their total influence over him. As he informs Hilde, he was brought up in a God-fearing home, and this is not only evident from his personal struggle with God, but reflected in the symbolism and the dramatic structure of the play as a whole. In constructing a high tower for his own house Solness defies God with his very own tower of Babel, and his rejection of God's will atop the church tower in Lysanger amounts to an inversion of Jesus' response to his temptation by the devil on the high mountain: Jesus refused the offer of becoming the lord of all the kingdoms of the world if he would renounce his service to God and worship the devil; Solness effectively accepts it. Solness must also be aware, at least subconsciously, that his climb of the tower at Lysanger came very close to reversing Jesus' response to the third and final temptation on the pinnacle of the temple of Jerusalem, where the devil dared him to cast himself down from the temple in order to be saved by God's angels as proof of his being the son of God. As Solness is now ten years older than he was in Lysanger, the likelihood of his succumbing to vertigo is so strong that his endeavour amounts to virtual suicide, as he himself appears to admit just before he decides to make the climb anyway: "[sadly]. Oh, Hilde ... I can't do a thing like that every day" (350). He must therefore be aware that the new climb represents a far more severe 
challenge to God than the climb in Lysanger, but in the event accepts his suicide as an integral part of the performance of his work of art by which he hopes to overcome, once and for all, his problems with life. This is confirmed by the fact that the cry which is heard at his fall comes from the crowd rather than from Solness himself: he himself is neither surprised nor terrified by his fall.

The relationship between the play's symbolism and certain stories in the Old and New Testament has been much discussed in the critical literature. However, while the artistic impact of The Master Builder undoubtedly owes a great deal to Ibsen's use of biblical symbolism, the entanglement of religious guilt with disease seems to have been suggested to Ibsen by Sophocles' King Oedipus. In that tragedy, the hero's guilt is compared to the plague: just as the plague with which the gods have struck Thebes as punishment for Oedipus' crimes of parricide and incest cannot be cured once it has attacked its victims, the seer Teiresias can diagnose, but not take away, Oedipus' guilt. Ibsen goes further than Sophocles, however: he not only makes Solness feel guilty for the death of the twins, but has him indirectly commit suicide, and it is his uncontrollable urge to die that makes Solness appear a victim of his psychiatric illness.

Solness' death thus reveals the true nature and extent of the madness from which he had suspected himself to be suffering in act 1 already. While Ragnar does not recognise Solness' unconscious suicidal urge, ${ }^{16}$ he at least understands the safeguarding

${ }^{16}$ Ronald Gray, Ibsen-a Dissenting View: A Study of the last twelve Plays (Cambridge: Cambridge University Press, 1977), 161, finds fault with Ibsen's directions that, along with a human body, "some planks and poles can be indistinctly glimpsed plunging down among the trees." According to Gray, these directions are evidence of Ibsen's intention to show the audience that Solness "did not break under his self-imposed task." While Gray does not discuss the likelihood of this indeed being the playwright's intention, he claims that it would be impossible for any production to make the audience distinguish the poles and planks from the falling body, "and grasp their significance." And he states: "Much that would seem improbable in a real context becomes much more easily acceptable in a world of wish-fulfilment, ironically portrayed as such. [...] Fantasy requires here the death-wish: Solness must come to grief at the final moment, yet nothing in the action requires it." Gray's attack on Ibsen's craftsmanship is misguided, since the stage direction in question can easily be explained from Ibsen's intention to make the end of the play concur with the symbolic context of the tower of Babel: in his fall he inadvertently takes with him "some poles and 
function of his fear of heights when he greets Hilde's announcement of Solness' decision to climb the tower with the scornful remark that Solness will "steer well clear of that" (345). Vertigo, unlike the fear of heights, only takes effect once the sufferer is already too high up to be able to make his way back down. Yet for all its powerful evocation of the potential of selfdestruction in Solness' hubris, vertigo is not the fundamental cause of his death: we sense that, even if his condition could have been cured in time (in a course of treatment which, ironically, is suggested by Ragnar's scornful comments [353] that Solness will "have to crawl down again on his hands and knees!" and come down to safety "long before he's got half-way" "), the much more serious problem of his unconscious wish to commit suicide would not have been solved, only postponed.

As it is his unconscious death-wish which has made him fall under Hilde's spell, and as Hilde has made his suicidal urge grow to the point of no return, it is clear that any treatment of this condition, to be successful, would not only have had to be quite different from anything contained in Ragnar's words, but also to have begun before Hilde's arrival: that is, in act 1, when Solness' fear of heights is still stronger than his death-wish and he turns to Dr Herdal for help.

The doctor, however, does the worst thing a doctor can do to a potential suicide: in order to allay Solness" fear that "youth is going to come here beating on the door," he simply "laughs":

planks" into the depth, not only destroying his own life, but also damaging the construction of the tower. However, Gray's remarks on fantasy, wish-fulfilment and death-wish are of course most apt.

${ }^{17}$ Ragnar's words come close to articulating a possible treatment for vertigo, which consists in making the sufferer feel comfortable with successively greater heights as he prepares to go up: a slow process, but the only one to prevent him from succumbing to the urge to fall. In a current handbook by David A. Tomb, Psychiatry, $6^{\text {th }}$ edition (Philadelphia, Baltimore, New York, London: Lippincott Williams \& Wilkins, 1999), 86, one finds the same treatment for "simple phobias": "Systematic desensitization (by reciprocal inhibition) uses a graded hierarchy of frightening stimuli, allowing the patient to 'work up' to facing the phobic object." According to Ellenberger (n. 10 above), 244, in the nineteenth century there was "a competition toward the isolation and description of new subforms of phobia: agoraphobia, claustrophobia, topophobia, and the like." Ellenberger could certainly have listed "acrophobia," that is fear of heights, to this list. 
"Well, good Lord, what of it?" (285). ${ }^{18}$ In his well-meaning attempt to reassure Solness that his fears are without foundation, Dr Herdal has forgotten the well-known fact that the threat of a sudden change in status, which Solness is clearly referring to, is one of the risk factors for suicide. ${ }^{19}$ When the doctor leaves on the grounds that he needs to see his patient, he is obviously referring to Aline, thereby implying that Solness does not need his attention at all.

Unable to see the warning signs of potential suicide in Solness' own utterances, the doctor is even less prepared to see the danger in Solness' relationship with Hilde and to protect him from her. Of course, she turns out to be the most dangerous person Solness could have met under the circumstances. Ironically, she herself unwittingly acts like a doctor who, unlike Dr. Herdal, knows all the right therapeutic means, but uses them for the wrong, and ultimately fatal, end. Like any competent doctor confronted with a potential suicide, she allows Solness to express his feelings of rejection and hopelessness, and responds by making hopeful and definite plans for the future with him; ${ }^{20}$ but her suggestion that he build a "castle in the air" appeals to his regressive rather than his mature side, which is the exact opposite of what a responsible doctor should do in order to counteract his patient's suicidal tendency. ${ }^{21}$ Without her, Solness' suicidal urge might have remained latent for a long time; Hilde is the catalyst that activates

\footnotetext{
18 Mitsuya Mori, "The Creation of Suspense in Act 1 of The Master Builder," Arbok 1967, ed. Ibsenforbundet (Oslo, Bergen, Tromsø: Universitetsforlaget, 1967), 85, is not concerned by the "shallowness of the rôle Herdal plays," and suggests that "the extraordinariness of the story impresses us so deeply that we are simply carried along."

${ }^{19}$ See, for instance, Tomb (n. 17 above), 73, under "Individual Risk Factors."

${ }^{20}$ Ibid., 74-75, includes the following directions in his "Treatment Principles" for patients at risk of suicide: "Develop a therapeutic alliance with the patient. Be concerned and accepting. [...] Allow the patient to express anger, 'unacceptable' thoughts, and feelings of rejection and hopelessness. [...] Be hopeful. Be definite. Make specific plans with and for the patient."

21 Tomb includes as one of his "Treatment Principles" that the doctor must "[a]ppeal to [the patient's] mature rather than his regressive side," and "deal with reality issues." With her concept of the castle in the air Hilde also counteracts another of Tomb's principles: that the doctor must "[a]ctively try to reduce social isolation and withdrawal."
} 
it sufficiently to overpower the remaining survival instinct manifested in his fear of heights. ${ }^{22}$ She alone has the means to do so because of the special bond they had developed at Lysanger and because of her ability to practise what is in effect a kind of hypnosis to achieve influence over his will. ${ }^{23}$ Shortly before making her suggestion that Solness build castles in the air, she speaks to him like a hypnotist: "Oh, if only one could fall asleep and leave the whole sorry business behind!" (339), she says, shutting her eyes and speaking in a soporific voice, "as though half asleep"; then, once again adopting an "ordinary voice" (340), she makes her suggestion of the castle in the air.

With his mistaken diagnosis (and, as it were, prophecy) that Solness is "more firmly established here now" (285) than he has ever been, Dr. Herdal shows a blindness to the facts that makes him appear like a reversed Teiresias, and his medical science becomes a false oracle. This is despite Solness' own confidence that the doctor is willing and able to track down the true nature of his disease, even if by methods that are not necessarily agreeable to him, by "snooping around here" so as to "keep an eye on [him]" (283). When Solness, "with a sly smile," half accusingly, half in admiration, suggests to the doctor: "You must be thinking that you've got me nicely launched now, eh, Doctor?" (283), he clearly means that the doctor has come at Aline's request, to draw an involuntary revelation of his insanity out of him. Sadly overestimating the doctor's intentions and skills in this respect, Solness has in fact already begun a kind of self-analysis at this

${ }^{22}$ Tomb points to the fact that suicidal patients are "usually ambivalent about death and often don't know why they are trying to kill themselves." As neither Solness nor Hilde are aware of his risk of suicide, Hilde cannot be expected to "point out that ambivalence to them [...]" as Tomb prescribes. While Solness' suicide results from his unconscious death wish, her role as the catalyst for the activation of this wish is not even subconsciously intentional, since she only wants to see him come as close to death as possible, but does not want him to die.

${ }^{23}$ While hypnotism and so-called animal magnetism or mesmerism, which were used for the treatment of both psychiatric and non-psychiatric illnesses since the end of the eighteenth century, had fallen into disrepute in the period from 1860 to 1880 , they became fashionable again from the beginning of the $1880 \mathrm{~s}$ with the establishment of the so-called Nancy School under its head Hippolyte Bernheim who in 1886 published his textbook De la suggestion et de ses applications à la thérapeutique (see Ellenberger [n. 10 above], 150). 
early stage, examining his own fears, clearly as much in need of psychoanalysis as he is dreading it. Unable to solve the problem on his own, and let down by the doctor, he falls prey to Hilde's fatal treatment.

Solness' expectation that Dr Herdal will analyse him to help him out of his predicament shows the prescience of Ibsen's preFreudian psychiatry: its implication is that even if Dr Herdal had diagnosed Solness' suicidal urge, he would not have had a direct cure for it, but would have had to take the time to use a psychoanalytical method similar to that which was developed by Freud only a number of years after Ibsen wrote The Master Builder. And yet it seems that Freud may not have been able to contribute to such an analysis as much as one might have expected. His main concern with regard to Ibsen, in whose plays he was well-read, was how they related to his theory of the Oedipus complex, and he was therefore far more interested in the play Rosmersholm, published six years before The Master Builder, where, in contrast to his later play, Ibsen had demonstrated that Sophocles' belief in man's ability to cope heroically with the truth of his failures was not necessarily outdated even at the end of the nineteenth century. ${ }^{24}$ In Rosmersholm, according to Freud's convincing interpretation, the heroine finds out that the sexual relationship she had with her adoptive father was in fact incestuous. Freud was thus able to use her fate as modern-day

\footnotetext{
${ }^{24}$ In Rosmersholm, the protagonist, Rebecca, who turns out to deserve the label of a heroine far more than Solness deserves to be called a hero, effectively murders her sexual rival Beate, whose husband Rosmer she wishes to marry, when she persuades Beate, who is unable to have children, to sacrifice her life for Rosmer to make it possible for him to marry Rebecca and thus have children by her. Yet in Rebecca's eyes her action is entirely in accordance with the principles in a book on "The Purpose of Marriage" that she inherited from her adoptive father. It is only when Rosmer, after the suicide of his wife, accuses himself of being responsible for her death, that Rebecca begins to sense her own guilt, and when Rosmer finally proposes to her, she rejects his proposal, and emphatically confirms her rejection once she learns from Rosmer's brother-in-law that her adoptive father had in fact been her natural father. Freud sees Rebecca's love for Rosmer as the reason for her eventual suicide, committed by a heroine who has finally returned to high moral standards ("Gewissens- und Adelsmensch"): Rebecca and Rosmer both drown themselves in the same river in which Beate had committed suicide.
} 
evidence for his theory of the Oedipus complex, ${ }^{25}$ and he could not have done so with The Master Builder, as there is no hint at an Oedipus complex in the protagonist or any of the other figures.

However, the plot of The Master Builder does lend itself to Freudian analysis in a more general sense, provided that one looks at Solness' past with one's mind open to the possibility of suppressed sexual desires lying behind his pangs of guilt: desires which, though quite different from an Oedipus complex, he tries in vain to sublimate in his work as a builder and artist, until his most ambitious creation, the castle in the air, leads to his final, tragic fall. Such an analysis, like Freud's own interpretation of Rosmersholm, can draw from the obvious parallels between The Master Builder and the Oedipus myth. However, its outcome must differ from Freud's interpretation of Rosmersholm for one main reason: in contrast to Freud's ahistorical perspective, Ibsen's reading of King Oedipus, as revealed in The Master Builder, included an awareness of the historical gap between the classical Greek humanism of Sophocles' tragedy and the heroic ideal of the pre-Sophoclean myth. In Sophocles' tragedy, that ideal is represented by the glorious hero Oedipus who had liberated the citizens of Thebes from the Sphinx by virtue of his wit, that is, by solving her riddle. ${ }^{26}$ By virtue of this deed he had obtained the kingdom of Thebes, as is alluded to in the verbal exchange between Oedipus and Tiresias at the beginning of the tragedy, where Tiresias pronounces his paradoxical prophecy that " $[\mathrm{t}] \mathrm{his}$

25 Sigmund Freud, "Some Character-Types met with in Psycho-Analytic Work" (1916), in The Standard Edition of The Complete Works, trans. from the German, general ed. James Strachey, collab. Anna Freud, vol. 14 (London: Allen and Unwin, 1957), 324-31. Freud (331) acknowledges that the incest motif in Rosmersholm had already been pointed out by Otto Rank, Das Inzestmotiv in Dichtung und Sage (1912). - In Rosmersholm, unlike The Master Builder, the incest is real rather than metaphorical.

26 Carl Robert, Oedipus: Geschichte eines poetischen Stoffs im griechischen Altertum (Berlin: Weidmannsche Buchhandlung, 1915), 56, states that the myth of Oedipus as the solver of the riddle of the Sphinx is at least as old as the "Schale des Meisters mit der Ranke", which dates from ca 530, with Oedipus solving the riddle in front of the Sphinx. Cf. Jennifer R. March, The Creative Poet (London: Institute of Classical Studies, Bulletin Supplement 49, 1987), 124. Robert's suggestion that this myth probably belongs to an even older tradition represented by the Oedipodia and the Thebais has met with controversy, but this is of no consequence to the case argued in this essay. 
day will give Oedipus birth and destroy him. His skill at riddles has ruined him," and Oedipus "replies that he does not care, if the city was saved, and enters the house as Tiresias predicts blindness and ruin at his back." 27 The Greek audience was already familiar with the riddle and with its solution by the young Oedipus, ${ }^{28}$ so that there was no need for Sophocles to refer to it himself directly at the end of the tragedy, when he reveals the sobering fact that Oedipus' answer to the Sphinx's riddle had in fact been superficial rather than ingenious: by blinding himself in punishment for not having seen that he had killed his father and slept with his mother, Oedipus finally turns into the true meaning of the riddle, without Sophocles having to put this into words. Oedipus himself, the supposed hero and saviour of Thebes, has become subject to the weaknesses of humanity and, in the prime of his life, needs a walking stick to find his way-he himself is the riddle's "animal on three legs."

Thus, the fabric of Sophocles' King Oedipus shows a value shift away from human wit as the ultimate heroic weapon towards an awareness of its limitations. This marks a double progression from an even earlier version of the heroic myth, where Oedipus had destroyed the power of the Sphinx by virtue of his physical strength. $^{29}$ In The Master Builder, this progression appears reversed. By following Hilde's demand that he climb the tower of his house in spite of his fear of heights, Solness subscribes to a concept of heroism as mental and physical strength that reminds us of Oedipus in the early pre-Sophoclean myth. Without his regressive heroism, he could not have climbed the tower, a neurotic performance driven by the highest aspiration as well as desperation. In reversing the cultural progress implicit in the

27 King Oedipus 438-43, as summarised by Ruth Scodel, Sophocles (Boston: Twayne Publishers, 1984), 59.

${ }^{28}$ Referring to vase paintings, Robert (n. 26 above), 56, shows that not only the riddle as such, but also its version in hexameters was known to the Greeks from the sixth century at the latest. In modern times, generations of pupils of Latin and Greek got to know the riddle and its solution by the young Oedipus, even without studying King Oedipus or Euripides' Phoenissae, which has the riddle in hexameters quoted both in the hypothesis and in the scholia on line 50. The words of the riddle are also quoted in Athenaeus and elsewhere.

${ }^{29}$ For the version of the myth where Oedipus destroys the power of the Sphinx by virtue of his physical strength, see Robert (n. 26 above), 49. 
Sophoclean myth, the play exposes the illusory nature of Solness' resolution of his midlife crisis. In combining his ascent with his downfall, the play exposes the explosive tension in Ibsen's own time between, on the one hand, an optimistic faith in the blessings of progress and, on the other, a self-destructive pessimism about its actual value.

For a full appreciation of all this it would be necessary to subject the parallels between The Master Builder and the Oedipus myth to a separate investigation, including not only the Sophoclean and pre-Sophoclean myth, but also the adaptations of the myth in the tragedies of Euripides and Seneca. ${ }^{30}$ Even so, it is clear that, according to Ibsen, society's problematic relationship with progress may lead to a psychiatric disturbance of epidemic proportions. Termed madness by the protagonist himself in the first act, this disease is shown in the course of the play to have just as much lethal power as the plague in Sophocles' King Oedipuswith the important difference that Oedipus is not only spared physical death by the plague, but also overcomes his temptation to commit suicide in response to his guilt, whereas Solness' insane attempt to avoid the effects of old age shows that he has himself been struck by the plague of his time: a fatal neurosis. In his case it leads to physical death, and other characters in the play end up as living dead. Solness' ill-fated tour de force in trying to overcome his fear of heights reflects the uneasy fascination with progress in Ibsen's time as well as our own, which on the one hand pressures people into pursuing their ambitions with an astonishing lack of concern for the danger to which they are exposing themselves and others, and on the other leaves them in the constant fear that their

${ }^{30}$ A detailed investigation of the role of the Oedipus myth in The Master Builder, with reference not only to the Sophoclean and pre-Sophoclean myth, but also to its adaptations in the tragedies of Euripides and Seneca, is provided by Hansgerd Delbrück, "Falling for the Sphinx: The Heritage of the Oedipus Myth in Henrik Ibsen's The Master Builder," Ibsen Studies, vol. 1 (2000): 30-53. There appears to be no trace in The Master Builder of the Oedipus tragedies by Corneille and Voltaire. While Ibsen may not have known these plays, they do not lend themselves to psychoanalytical analysis in the first place. See John E. Jackson, "Edipe contre Freud: l'exemple de Voltaire", in Antiquitates Renatae: Deutsche und Französische Beiträge zur Wirkung der Antike in der europäischen Literatur, Festschrift Renate Böschenstein (Würzburg: Königshausen, Neumann, 1998), 7182. 
success will collapse. This fear leads them to dread, like Solness in his fear of heights, the very achievement they are aiming for, and even to yearn for their own downfall as the only means to quell their fears, just as Solness subconsciously wishes to die.

In providing not only a clear-cut diagnosis of Solness' condition, but also the suggestion of psychoanalysis as the obvious cure, Ibsen was nevertheless well aware of the complicated nature of the disease and, like Freud, ${ }^{31}$ of the limited healing power of the recommended treatment. However, Ibsen also shared Freud's conviction $^{32}$ that, even if we are rightly sceptical of success, we must nevertheless continue to look for analytical solutions to the problem. This positive version of the ambivalence of his time defines the tragedy of the Master Builder and has secured its longterm success: while Ibsen himself used the term "play" ("skuespill") rather than "tragedy" to contrast the contemporary basis of his plays with the seemingly timeless art of tragedy aimed at by Goethe and Schiller in their classical works, Ibsen's advanced pre-Freudian psychiatry has helped to make The Master Builder

31 According to Anthony Clare, "Freud's cases: The clinical basis of psychoanalysis," in The Anatomy of Madness: Essays in the History of Psychiatry, vol. 1, ed. W. F. Bynum, Roy Porter and Michael Shepherd (London, New York: Tavistock, 1985), 273, Freud's warning against too much optimism as to the healing effect of psychoanalysis was twofold. As early as 1905 he "expressed the view [...] that certain disorders, most notably serious psychotic illnesses such as schizophrenia, manic-depressive psychoses, organic psychoses, and states of confusion, were unsuitable" for psychoanalysis; and at the end of his life, in his essay Analysis Terminable and Interminable, he expressed himself "with considerable caution, even uncertainty" in a much more general sense: "One has the impression that one ought not to be surprised if it should turn out in the end that the difference between a person who has not been analysed and the behaviour of a person after he has been analysed is not so thorough-going as we aim at making it and as we expect and maintain it to be [...] analysis in claiming to cure neuroses by ensuring control over instinct is always right in theory but not always right in practice."

32 "But Freud never quite withdrew the claim for therapeutic efficacy as is clear from his comments in one of the second series of introductory lectures on psychoanalysis which he wrote in 1932 and 1933 [...]. While acknowledging that he was never a therapeutic enthusiast and that psychoanalysis, like any other treatments, has 'its triumphs and its defeats, its difficulties, its limitations, its indications', compared with the other psychotherapeutic procedures 'psychoanalysis is beyond doubt the most powerful"' (Clare, ibid.). 
not only a play of striking modernity, but a classic in its own right. This can be seen from the impact it had on the Swiss playwright, Friedrich Dürrenmatt, arguably the pre-eminent dramatist of all German-speaking countries in the third quarter of the twentieth century. In the 1950s, Dürrenmatt believed that tragedy as a genre had outlived its natural life span and needed to make way for comedy, because, as he stated in a paper he wrote in 1954, in our time our individual actions have become of far less consequence for our fate than those of society as a whole. ${ }^{33}$ Yet he could have supported the latter claim by referring to Ibsen's tragedy The Master Builder: Solness is let down not so much by anybody's intellectual or moral defect, including his own, as by the slow progress of medical science. And in fact Dürrenmatt's own famous tragicomedy, The Visit (1956), which placed him in the avantgarde of European dramatists, appears to owe much of its dramaturgical impact to lessons he had learned from Ibsen. Rather than a dramatic form that is superior to tragedy, as Dürrenmatt would want us to believe, The Visit is a comic adaptation of much of Ibsen's play. ${ }^{34}$ It is therefore significant that in the $1970 \mathrm{~s}$, when Dürrenmatt abandoned not only Ibsen's analytical dramaturgy, but also the distinction between comedy and tragedy, ${ }^{35}$ his new plays no longer met the keen public interest that his earlier tragicomedies such as The Visit had enjoyed and continue to enjoy, just as The Master Builder itself continues to attract an audience.

\footnotetext{
33 "In the routine muddle of our century, in this last dance of the white race there are no longer any guilty people nor any responsible ones either. Nobody can do anything about it and nobody wanted it to happen [...] We are too collectively guilty, too collectively embedded in the sins of fathers and forefathers. We are only grandchildren now. That is our bad luck, not our guilt: guilt only exists now as a personal accomplishment, as a religious act. Only comedy can still get at us." (Friedrich Dürrenmatt, Writings on Theatre and Drama, trans. and intro. H. M. Waidson [London: Cape, 1976], 83-84.)

${ }^{34}$ The comic impact of The Visit, like the tragic impact of The Master Builder, stems to a large extent from the playwright's skills in setting the characters' fear of slowly falling behind their own ambitions against their fear of immediate and complete ruin, which gradually turns into an uncontrollable attraction.

${ }^{35}$ F. Dürrenmatt in his preface to Porträt eines Planeten [Zürich: Arche, 1971], 10: "The world we are living in is neither intact nor profound, but entangled in disastrous banalities. [...] There is no cabaret in view of the certain end [of the planet]—who, after all, would still be willing to laugh?" (Translation mine)
} 
However, neither Solness nor Hilde, nor any other character in The Master Builder, are capable of displaying the detachment from their own fate that is characteristic of the protagonist of The Visit, ${ }^{36}$ so that The Master Builder has stood the test of time with the distinct flavour of tragedy rather than comedy or tragicomedy.

36 According to Dürrenmatt's postscript to The Visit, trans. Patrick Bowles (London: Cape, 1962), 106, detachment from the world and from herself is the hallmark of the play's protagonist: "This lady has a sense of humour and it mustn't be overlooked, for she is quite as detached from people as from saleable objects and detached from herself as well." 